\title{
Simulator Storage Tank: Sebuah alat praktikum untuk melatih pengoperasian tangki ${ }^{1)}$
}

\author{
Nurcahyo $^{2)}$, Rispiandi ${ }^{3)}$, Randy Surya Kusumah ${ }^{4)}$, Sandra Sopian ${ }^{4)}$ \\ Jurusan Teknik Kimia, D3 Teknik Kimia, Politeknik Negeri Bandung,Bandung 40012 \\ E-mail:nurcahyoms@yahoo.com,sandrasopian@gmail.com,randysurya93@gmail.com
}

\begin{abstract}
ABSTRAK
Storage tank merupakan tangki penyimpanan untuk fluida cair dan gas. Dalam penelitian ini, storage tank digunakan untuk proses loading dan unloading fluida cair dan gas dengan tujuan untuk melihat fenomena yang akan terjadi akibat kekeliruan karena venting tidak dibuka yang akan menimbulkan potensi ledakan untuk proses loading dan bahaya collapse untuk proses unloading. Parameter yang digunakan adalah variasi laju alir volumetrik terhadap waktu dan tekanan ketika ledakan serta collapse. Adapun spesifikasi dari storage tank yang dibuat sesuai dengan desain dan rancangan dari API 620 dan 650 dengan ketinggian $50 \mathrm{~cm}$, diameter $20.32 \mathrm{~cm}$ dan ketebalan $0.7 \mathrm{~cm}$ dari bahan carbon steel. Simulator keamanan dari storage tank ini menekankan pada aspek fenomena dari keamanan pengoperasian storage tank. Indikator untuk bahaya ledakan adalah balon, karet pipet dan plastik tebal, sementara untuk simulasi bahaya collapse, indikator yang digunakan adalah botol plastik dengan ukuran 450, 700 dan $1600 \mathrm{ml}$. Setiap indikator tersebut dimaksudkan sebagai sebuah simulator dari bahaya keamanan pada storage tank, tetapi tidak merepresentasikan daripada kekuatan tangki. Indikator yang digunakan untuk melihat fenomena ledakan saat proses loading maupun collapse saat proses unloading menekankan pada aspek penyadaran terhadap orang atau operator yang bersangkutan bahwa untuk setiap kekeliruan dari proses loading maupun unloading akan mengakibatkan konsekuensi. Dalam skala industri yang lebih besar dan dengan fluida yang lebih sensitif dan berbahaya, kekeliruan ini bisa fatal dan tidak bisa ditolerir. Hasil dari penelitian dan uji simulasi kemanan tersebut untuk proses loading fluida cair diperoleh tekanan maksimumnya 1 barg untuk indikator karet pipet pada nilai laju alir volumetrik pada $30 \mathrm{l} / \mathrm{min}$ dengan waktu loading 19.48 detik. sementara untuk proses loading fluida gas mempunyai tekanan maksimum sebesar 0.6 barg untuk indikator karet pipet pada nilai laju alir volumetrik $30 \mathrm{l} / \mathrm{min}$ dengan waktu pengisian adalah 11.91 detik untuk indikator karet pipet. sementara untuk proses unloading fluida cair botol berukuran $1600 \mathrm{ml}$ menunjukan ketahanan terhadap collapse yang lebih kuat (lama) dengan waktu 0.58 detik untuk laju alir volumetrik maksimumnya. Terakhir untuk proses unloading fluida gas bahwa ketahanan botol berukuran $400 \mathrm{ml}$ lebih kuat dengan waktu collapse yaitu 13.61 detik. Adapun indikator optimum untuk penelitian pada proses loading adalah dengan menggunakan karet pipet, dan proses unloading dengan menggunakan botol berukuran $700 \mathrm{ml}$.
\end{abstract}

Kata kunci: storage tank, loading, unloading, ledakan, collapse, indikator, simulator keamanan.

1) Merupakan karya tugas akhir dengan judul asli : Rancang Bangun Dan Uji Karakteristik Simulator Keamanan Storage Tank

2) Pembimbing I dalam proses penyelesaian tugas akhir

3) Pembimbing II dalam proses penyelesaian tugas akhir

4) Pelaksana tugas akhir 


\section{PENDAHULUAN}

Storage tank atau yang lebih sering dikenal dengan tangki penyimpanan merupakan salah satu unit atau peralatan yang terdapat dalam bidang rekayasa proses baik dalam skala kecil, menengah ataupun industri besar. Alat ini banyak ditemukan di industri kimia seperti industri oil and gas, petrokimia, polimer, dan yang lainnya. Kegunaan storage tank ini sangat luas, selain untuk penyimpanan, juga sebagai media untuk mengalirkan fluida ke tangki atau unit yang lainnya.

Oleh sebab itu, safety atau keamanan dari tangki ini mendapat prioritas utama dalam bidang K3 (Keselamatan dan Kesehatan Kerja). Penelitian ini akan berupaya untuk memberikan gambaran tentang potensi bahaya yang akan terjadi bila prosedur pengoperasian tangki tidak ditaati dan untuk memberikan pemahaman kepada mahasiswa teknik kimia Politeknik Negeri Bandung yang umumnya belum mengenal cara pengoperasian storage tank yang benar.

Salah satu yang menjadi kepentingan dari mempelajari storage tank adalah karena sering terjadinya kecelakaan pada saat pengisian dan pengosongan tangki ketika prosedur yang harus ditaati dilanggar oleh operator. Sementara prosedurnya, untuk setiap pengisian dan pengosongan tangki terdapat Standard Operation Procedure (SOP) yang harus ditaati.

Storage tank yang dibuat berdasarkan standard API 620 dan 650 yang ukurannya telah disesuaikan untuk kebutuhan laboratorium dengan menggunakan material dari jenis carbon steel. Adapun uji karakteristik terhadap tangki ini adalah variabel laju alir volumetrik fluida dengan jenis fluida air dan udara tekan untuk menentukan batasan maksimum dari variabel yang diujikan terhadap keamanan untuk pengoperasian tangki. Pada realisasinya, Tugas Akhir ini berupaya untuk membuat suatu simulator keselamatan dalam penggunaan dan pengoperasian storage tank.

Tujuan penelitian ini adalah untuk membuat simulasi kecelakaan dari pengoperasian storage tank yang keliru. Parameter dari kecelakaan tersebut dilihat dari indikator yang dipasang di bagian venting dengan proses loading dan unloading untuk fluida cair dan gas.

\section{TINJAUAN PUSTAKA}

Storage tank digunakan untuk menyimpan fluida dalam kapasitas yang besar, khususnya untuk cairan dan gas (2010, Oxford Dictionary dan Thesaurus). Di USA, storage tank dioperasikan pada tekanan rendah yang membedakannya dengan pressure vessels. Storage tank biasanya berbentuk silindris, yang tegak lurus terhadap tanah dengan bagian dasar yang rata, dan bagian atap tipe fixed atau floating. Selain berfungsi untuk menyimpan fluida, storage tank digunakan pula untuk distribusi aliran dari satu tangki ke tangki lainnya dan untuk menyimpan produk. Lebih jauhnya, storage tank juga diharapkan mampu untuk mempertahankan fluida yang ada di dalamnya dari segala jenis kontaminan dan kerusakan (Renaningtyas, 2010).

Desain storage tank disesuaikan berdasarkan jenis fluida dan karakteristik dari fluidanya itu sendiri, sehingga desain tangki untuk fluida gas akan berbeda dengan desain tangki untuk fluida cair. Tangki untuk fluida yang mudah terbakar dengan yang tidak juga akan berbeda dalam segi material yang digunakan untuk pembuatan storage tank dan karakteristisasinya.

Standard untuk storage tank yang diatur oleh API dituangkan dalam bentuk dokumen tertulis di bagian API STD 620 tentang Recommended tanks for Design and Construction of Large, Welded, LowPressure Storage tanks. Dimana diatur beberapa hal mengenai konstruksi tangki, antara lain:

a. Volume ruang uap: diatas level desain dari high liquid diatas nilai kapasitas jangan kurang dari $2 \%$ dari kapasitas total liquid.

b. Suhu dari liquid, uap atau gas di dalam tangki atau ketika masuknya tidak boleh lebih dari $250^{\circ} \mathrm{F}$.

c. Tekanan maksimum tangki disesuaikan dengan rating nominal tekanan untuk tangki dan tidak boleh lebih dari $15 \mathrm{Ibf} / \mathrm{in} 2$ gauge (1,034 bar g).

d. Sistem perpipaan dan material pipa yaitu Carbon steel pipa sesuai dengan standard ASTM A 53. 
Tangki yang dibuat pada penelitian ini termasuk jenis Aboveground tank atau tangki diatas permukaan tanah dan termasuk fixed cone roof tank yang dilengkapi dengan vent di bagian atasdan drain di bagian bawah dengan modifikasi bentuk dop.

\section{METODE}

Metode yang digunakan untuk menunjang penelitian ini terdiri dari beberapa tahap yang secara berurutan adalah sebagai berikut; perancangan alat, pembuatan alat, uji karakteristik dan analisis data.

Tahap perancangan alat meliputi desain dan sketsa alat dengan menggunakan software Autocad 2011 setelah sebelumnya ditentukan ketinggian, ketebalan dan diameter tangki sebagai hasil proyeksi dari ketentuan yang tercantum di API 620 dan 650 .

Pembuatan alat storage tank sebagai hasil dari rancang bangun dibantu oleh bengkel fabrikasi di wilayah bandung, sementara kelengkapannya seperti sistem perpipaan diselesaikan oleh penulis sendiri.

Uji karakteristik terhadap storage tank yang sudah dibuat meliputi bahaya ledakan dari proses loading fluida cair dan gas serta bahaya collapse dari proses unloading fluida cair dan gas. Indikator untuk bahaya ledakan adalah balon, karet pipet dan plastik, Sementara indikator untuk bahaya collapse terdiri dari botol berukuran $450 \mathrm{ml}, 700 \mathrm{ml}$ dan $1600 \mathrm{ml}$.

Analisis data dari hasil uji karakteristik sebelumnya adalah penentuan kurva laju alir terhadap waktu untuk setiap parameter yang diujikan kemudian dibuat untuk masingmasing tersebut kurva dan melihat tren atau kecenderungan dari setiap fenomena yang terjadi.

\section{DISKUSI}

\subsection{Proses Loading Fluida Cair}

Hasil penelitian dari bahaya ledakan karena proses loading fluida cair ditampilkan pada kurva dibawah ini untuk setiap indikator yang di ujikan.

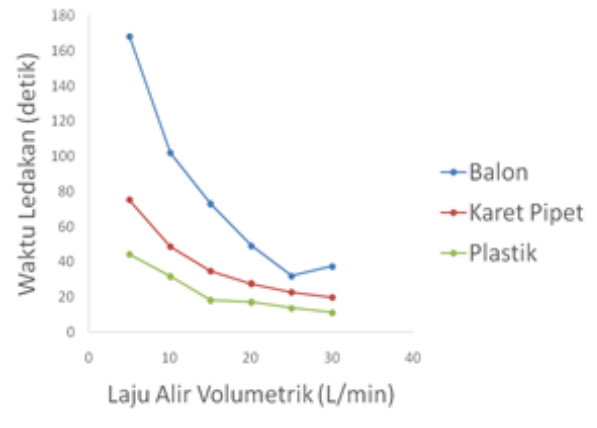

Gambar 1. Kurva laju alir volumetrik terhadap waktu ledakan setiap indikator pada proses loading fluida cair.

Waktu ledakan setiap indikator terhadap laju alir volumetrik menunjukan kecenderungan menurun bahwa dengan semakin besarnya laju alir volumetrik waktu ledakan lebih cepat. Terdapat fenomena yang menarik dari indikator balon bahwa pada nilai $30 \mathrm{~L} / \mathrm{min}$ trend kurva cenderung naik. Hal ini disebabkan karena terbentuknya dua zona yaitu zona diam dan zona gerak sesuai dengan Hukum Newton I dimana zona gerak telah terlampaui sehingga kemampuan indikator untuk mempertahankan kondisinya terhadap laju alir beralih ke zona diam hal tersebut disebabkan pula oleh sifat balon yang sangat elastis. Berbeda dengan karet pipet atau plastik yang cenderung tidak terlalu elastis dan rigid. Namun sebelum meledak ketiganya melalui tahapan yang sama, yaitu tahap elastis, plastik region dan fracture (meledak).

Dari keseluruhan indikator yang di uji terlihat mempunyai kecenderungan yang sama yaitu dengan semakin besarnya laju alir volumetrik menunjukan waktu ledakan semakin cepat. Tetapi dari ketiga jenis indikator, balon menunjukan waktu yang relatif lebih lama dibanding indikator yang lainnya.

Tren tekanan dari beberapa indikator berbeda sesuai dengan karakteristik dari indikatornya itu sendiri. Tekanan balon cenderung tetap sebesar 0 barg disebabkan karena sifat balon yang elastis sehingga semua tekanan dari tangki masuk dan memenuhi balon sebelum meledak. 


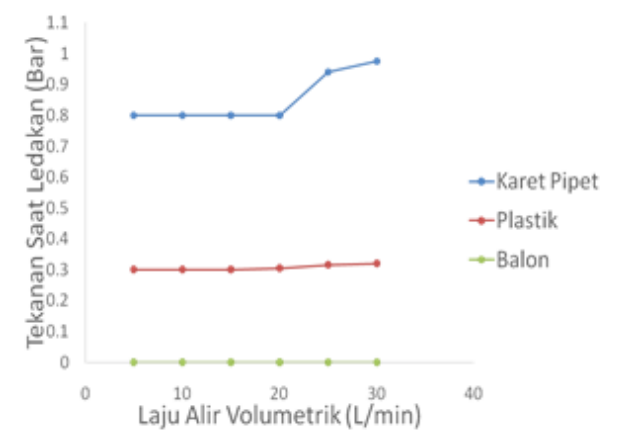

Gambar 2. Kurva laju alir volumetrik terhadap tekanan saat ledakan untuk setiap indikator pada proses loading fluida cair.

Adapun untuk indikator plastik ledakan terjadi pada tekanan 0.3 bar gauge yang menunjukan bahwa tekanan ini merupakan tekanan maksimal yang menyebabkan plastik meledak. Dari penelitian didapat bahwa ledakan bervariasi di badan plastik ataupun sambungan pada plastik sehingga dapat dikatakan bahwa kekuatan plastik sama rata pada setiap bagiannya.

Kemudian untuk karet pipet menunjukan fenomena yang berbeda karena pada titik tertentu tekanan saat ledakan mengalami kenaikan. Karet pipet mempunyai dua zona yang persis seperti kasus hukum I Newton tentang kelembaman benda. Zona 1 merupakan zona gerak yang berada pada rentang laju alir 5 hingga $20 \mathrm{l} / \mathrm{m}$, dan zona diam pada saat terjadi kenaikan tekanan untuk laju alir 25 hingga 30 l/m.

\section{Proses Loading Fluida Gas}

Hasil penelitian dari bahaya ledakan karena proses loading fluida gas ditampilkan pada kurva dibawah ini untuk setiap indikator yang di ujikan.

Pada proses loading fluida gas dengan indikator balon, waktu ledakan semakin cepat seiring dengan beasarnya laju alir. Namun, sama halnya pada fluida cair tekanan pada saat ledakan tidak terbaca pada barometer.

Pada percobaan loading storage tank dengan menggunakan karet pipet sebagai indikatornya nilai tekanan maksimum yang diperoleh adalah 0.6 bar gauge dengan laju alir volumetrik maksimal $30 \mathrm{l} / \mathrm{min}$ serta waktu pengisian sekitar 15.945 detik.

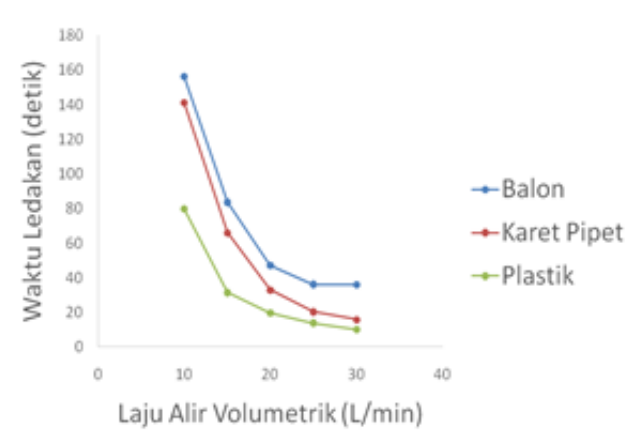

Gambar 3. Kurva laju alir volumetrik terhadap waktu ledakan setiap indikator pada proses loading fluida gas.

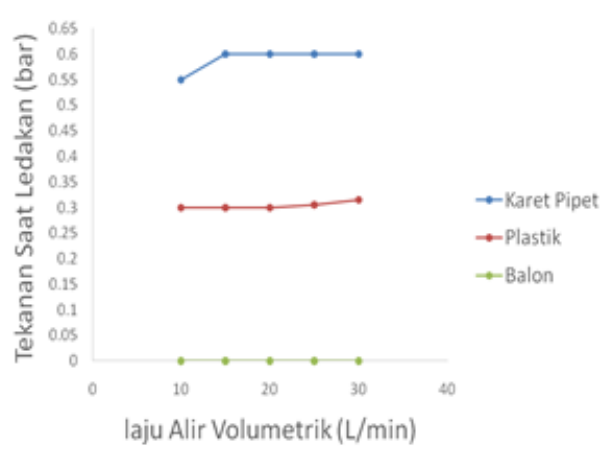

Gambar 4. Kurva laju alir volumetrik terhadap tekanan saat ledakan untuk setiap indikator pada proses loading fluida gas.

Pada percobaan loadingStorage tank dengan menggunakan plastik tebal sebagai indikatornya nilai tekanan maksimum pada saat ledakan yang diperoleh adalah 0.3 bar gauge untuk setiap variasi laju alir volumetrik.

Perbedannya terdapat pada waktu yang dibutuhkan untuk mencapai tekanan sebesar 0.3 bar gauge. Artinya, semakin besar laju alir waktu yang dibutuhkan untuk mencapai tekanan tersebut semakin cepat.

\section{Proses Unloading Fluida Cair}

Pada proses unloading fluida cair dengan menggunakan botol ukuran 450, 700 dan $1600 \mathrm{ml}$ sebagai indikator diperoleh kurva laju alir volumetrik terhadap waktu collapse adalah sebagai berikut: 


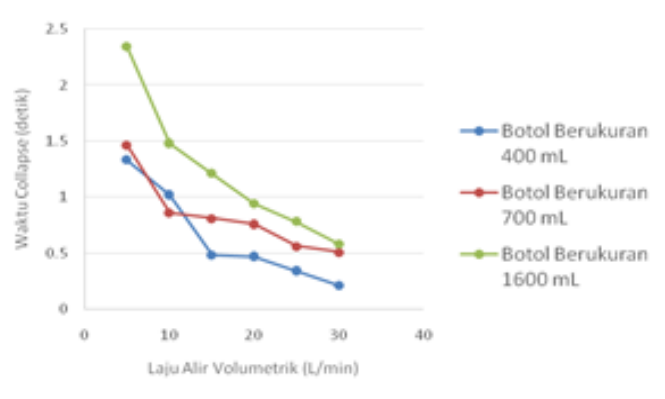

Gambar 5. Kurva laju alir volumetrik terhadap waktu collapse setiap indikator pada proses unloading fluida cair.

Pada kurva tersebut terlihat bahwa untuk laju alir volumetrik yang paling rendah, botol berukuran $1600 \mathrm{ml}$ mempunyai waktu collapse yang lama, artinya botol berukuran $1600 \mathrm{ml}$ mempunyai ketahanan yang relatif tinggi untuk bahaya collapse.

Hal ini bisa dipahami mengingat kenyataan bahwa untuk proses unloading fluida cair ruang untuk udara yang tersedia pada botol sangat ditentukan oleh volume dari botol itu sendiri, sehingga botol dengan ukuran 1600 $\mathrm{ml}$ relatif mempunyai ruang lebih besar dibanding botol lainnya.

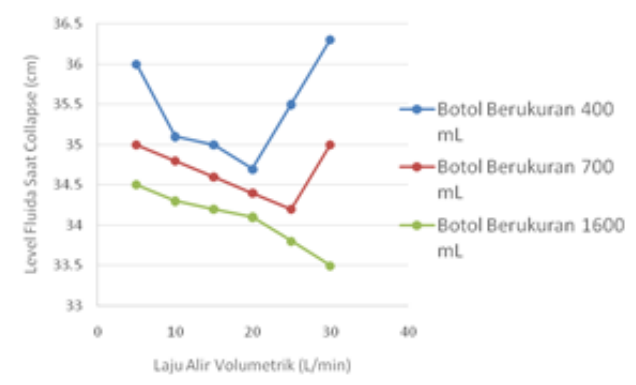

Gambar 6. Kurva laju alir volumetrik terhadap tekanan saat collapse untuk setiap indikator pada proses unloading fluida cair.

Kurva laju alir volumetrik terhadap level fluida ketika proses unloading fluida cair untuk setiap indikator botol beragam ukuran menunjukan hasil yang berbeda. Tetapi mempunyai fenomena yang sama bahwa pada titik tertentu level fluida akan naik.

Pada botol berukuran $450 \mathrm{ml}$ level fluida menurun hingga laju alir $201 / \mathrm{m}$, dan setelahnya menunjukan kenaikan. Hal ini terjadi karena batas zona diam dari botol untuk bahaya collapse sudah terlampaui, dan hasilnya pada laju alir 25 dan $30 \mathrm{l} / \mathrm{m}$ botol tidak bisa mempertahankan kondisi geraknya sehingga mengalami collapse yang mengakibatkan level fluida yang tersisa di storage tank lebih banyak.

Sementara untuk botol berukuran $700 \mathrm{ml}$ titik kenaikan atau batas zona gerak adalah pada laju alir $25 \mathrm{l} / \mathrm{m}$. Sementara pada botol berukuran $1600 \mathrm{ml}$ zona diam belum tercapai hingga nilai laju alir maksimum 30 $1 / \mathrm{m}$ sehingga tren kurva cenderung terus menurun.

\section{Proses Unloading Fluida Gas}

UnloadingStorage tank dengan menggunakan fluida gas atau vakum dengan indikator yang sama seperti untuk fluida cair, yaitu botol plastik berbagai ukuran. Pada kondisi ini terdapat beberapa perbedaan dengan fluida cair seperti variasi laju alir yang disesuaikan dengan kemampuan pompa vakum yang terdapat di lab.

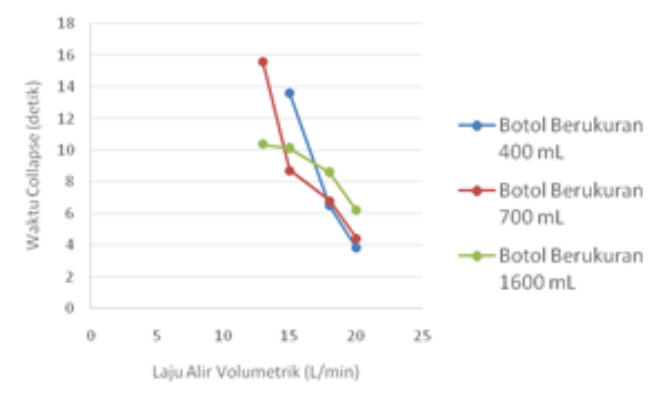

Gambar 7. Kurva laju alir volumetrik terhadap waktu collapse setiap indikator pada proses unloading fluida gas.

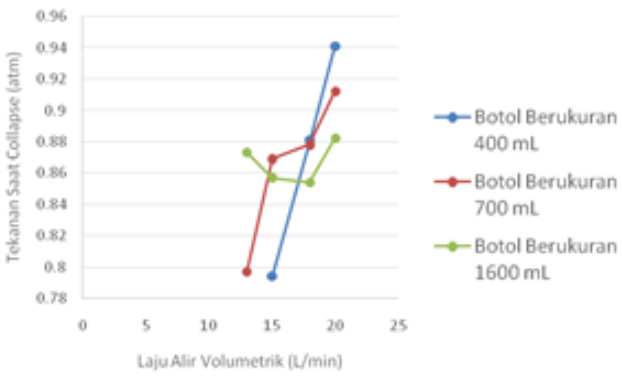

Gambar 8. Kurva laju alir volumetrik terhadap tekanan saat collapse untuk setiap indikator pada proses unloading fluida gas.

Pada botol berukuran $700 \mathrm{ml}$ trend tekanan cenderung semakin besar seiring dengan kenaikan laju alir sedangkan pada botol berukuran $1600 \mathrm{ml}$ trend tekanan sempat mengalami penurunan. Hal ini disebabkan 
botol tidak bisa mempertahankan sifat geraknya. Perbedaan dari waktu collapse disebabkan oleh momen inersia dari masingmasing botol tersebut. Momen inersia adalah ukuran kemalasan suatu benda untuk mengubah keadaan gerak rotasi nya (karena pengaruh torsi).

Torsi ini dipengaruhi oleh gaya dan lengan gaya. Gaya pada kasus collapse ini merupakan gaya tarik yang berasal dari pompa vakum pada saat proses unloading. Gaya ini pula yang menyebabkan adanya perubahan bentuk pada indikator botol yang dalam kasus ini botol remuk. Remuknya botol ini disebabkan oleh adanya perubahan struktur molekul penyusun botol yang disebabkan karena adanya gaya tarik tersebut.

Selain itu, perubahan bentuk dari botol ini dipengaruhi oleh besarnya jarak lengan gaya dari sumbu rotasi. Dari percobaan didapatkan bahwa terdapat perbedaan pada fenomena collapse untuk setiap jenis botol. Botol berukuran $1600 \mathrm{ml}$ cenderung mempunyai ketahanan lebih rendah dibanding botol berukuran $700 \mathrm{ml}$ maupun $400 \mathrm{ml}$. Hal ini disebabkan karena jarak lengan gaya dengan sumbu rotasi pada botol berukuran $1600 \mathrm{ml}$ lebih besar sehingga ketahanan botol berukuran $1600 \mathrm{ml}$ terhadap gaya tarik yang dikenakan lebih rendah. Oleh sebab itu, tekanan yang dibutuhkan pada proses collapse botol berukuran $400 \mathrm{ml}$ lebih besar dibanding botol ukuran lainnya untuk laju alir volumetrik yang sama. Hal ini juga diperkuat dari hasil percobaan dimana untuk laju alir rendah yaitu $10 \mathrm{l} / \mathrm{min}$ pada proses unloading, botol berukuran $1600 \mathrm{ml}$ sudah mengalami collapse berbeda dengan botol berukuran $400 \mathrm{ml}$ yang mengalami collapse pada laju alir $15 \mathrm{l} / \mathrm{min}$.

\section{KESIMPULAN}

Hasil penelitian ini adalah berhasil dibuatnya simulator storage tank untuk skala laboratorium yang memiliki spesifikasi ; tebal tangki $0.7 \mathrm{~cm}$, diameter tangki 20.32 $\mathrm{cm}$ dan tinggi tangki $50 \mathrm{~cm}$ dengan bahan carbon steel sesuai standard API 620 dan 650 .

Sementara untuk parameter laju alir volumetrik terhadap waktu ledakan dari fluida car dan gas untuk proses loading diperoleh simpulan bahwa semakin besar laju alir volumetrik maka semakin cepat pula waktu terjadinya ledakan dan waktu collapse pada indikator.

Waktu terjadinya ledakan dan tekanan saat ledakan pada fluida cair lebih cepat dan lebih besar dibanding fluida gas. Adapun untuk waktu terjadinya collapse pada fluida cair lebih cepat dibanding fluida gas.

Kemudian penentuan indikator optimum untuk penelitian selanjutnya adalah sebagai berikut: Proses loading dengan menggunakan karet pipet, dan proses unloading dengan menggunakan botol berukuran $700 \mathrm{ml}$.

\section{DAFTAR PUSTAKA}

1) API Standard 2000. 1998. Venting Athmospheric and Low-Pressure Storage Tanks. United States of America: American Petroleum Institute.

2) API Standard 620 Tenth Edition. 2002. Design and Construction of Large, Welded, Low-Pressure Storage Tanks. America: American Petroleum Institute.

3) API Standard 650 Tenth Edition. 2000. Welded Steel Tanks for Oil Storage.America: American Petroleum Institute.

4) ASME. 2001. Rules for Construction of Pressure Vessels VIII-Div 2 Alternative Rules. New York: The American Society of Mechanical Engineers.

5) Effendi, Asnal. tt. Momen Inersia. Padang: Institut Teknologi Padang.

6) Geyer, Wayne B. 2000. Handbook Of Storage Tank Sistems. New York: Marcel Dekker, Inc.

7) Gunawan, Agus Tri. 2013. Sekilas Mengenai Storage Tank. http://air.eng.ui.ac.id/ [Diakses pada 27 Juni 2015]

8) Mujiarto, Iman. 2005. Sifat dan Karakteristik Plastik dan Bahan Aditif. Semarang: AMNI.

9) Newton, Issac. Mathematical Principles of Natural Philosophy, translated into english by Andrew Motte, First American Edition. New York, 1846.

10) Pertamina. 1995. Panduan Suplai Dan Distribusi Elpiji. Surabaya: Pertamina LPG Filling Plant. 8

11) Pertamina. 2009. Maintenance House LPG Filling Plant TG. Perak Surabaya (2009). Surabaya: Pertamina LPG Filling Plant. 
12) Prayudha, Edo Gutawa. 2010. Deformasi.

http://edogp.blogspot.com/2010/02/defo rmasi.html [Diakses pada 26 Juni 2015]

13) Renaningtyas, Intan, dkk. 2010. Perawatan Storage Tank Gas LPG Dalam Upaya Pencegahan Terjadinya Ledakan. Malang: Universitas Negeri Malang.

14) Silver, Jerry. 2013. Newton First Law Experiment.

http://www.education.com/sciencefair/article/explore-more-aboutnewton's First-Law-of-motion-or-thelaw-of-inertia/ [Diakses pada 27 Juni 2015]

15) Sinaga, Parlin. tt. Material Plastik. Jakarta: PT. Sugitek Indotama

16) Anonim. tt. Tangki Penyimpanan. Medan: Universitas Sumatera Utara. 
